University of Nebraska - Lincoln

DigitalCommons@University of Nebraska - Lincoln

Publications, Agencies and Staff of the U.S.

Department of Commerce

U.S. Department of Commerce

1997

\title{
DISTRIBUTION AND ABUNDANCE OF THE AMAZON RIVER \\ DOLPHIN (INIA GEOFFRENSIS) AND THE TUCUXI (SOTALIA FLUVIATILIS) IN THE UPPER AMAZON RIVER
}

\author{
Omar Vidal \\ Instituto Tecnológico y de Estudios Superiores de Monterrey (ITESM) \\ Jay Barlow \\ U.S. National Marine Fisheries Service, jay.barlow@noaa.gov \\ Luis A. Hurtado \\ Instituto Tecnológico y de Estudios Superiores de Monterrey (ITESM) \\ Instituto Tecnológico y de Estudios Superiores de Monterrey (ITESM) \\ Patricia Cendón \\ Instituto Tecnológico y de Estudios Superiores de Monterrey (ITESM) \\ See next page for additional authors
}

Follow this and additional works at: https://digitalcommons.unl.edu/usdeptcommercepub

Part of the Environmental Sciences Commons

Vidal, Omar; Barlow, Jay; Hurtado, Luis A.; Instituto Tecnológico y de Estudios Superiores de Monterrey (ITESM); Cendón, Patricia; and Ojeda, Zully, "DISTRIBUTION AND ABUNDANCE OF THE AMAZON RIVER DOLPHIN (INIA GEOFFRENSIS) AND THE TUCUXI (SOTALIA FLUVIATILIS) IN THE UPPER AMAZON RIVER" (1997). Publications, Agencies and Staff of the U.S. Department of Commerce. 322. https://digitalcommons.unl.edu/usdeptcommercepub/322

This Article is brought to you for free and open access by the U.S. Department of Commerce at DigitalCommons@University of Nebraska - Lincoln. It has been accepted for inclusion in Publications, Agencies and Staff of the U.S. Department of Commerce by an authorized administrator of DigitalCommons@University of Nebraska - Lincoln. 


\section{Authors}

Omar Vidal, Jay Barlow, Luis A. Hurtado, Instituto Tecnológico y de Estudios Superiores de Monterrey (ITESM), Patricia Cendón, and Zully Ojeda 
MARINE MAMMAL SCIENCE, 13(3):427-445 (July 1997)

(C) 1997 by the Society for Marine Mammalogy

\title{
DISTRIBUTION AND ABUNDANCE OF THE AMAZON RIVER DOLPHIN (INIA GEOFFRENSIS) AND THE TUCUXI (SOTALIA FLUVIATILIS) IN THE UPPER AMAZON RIVER
}

\author{
OMAR VIDAL ${ }^{1}$ \\ Departamento de Ciencias Marinas and Centro de Conservación y \\ Aprovechamiento de los Recursos Naturales (CECARENA), \\ Instituto Tecnológico y de Estudios Superiores de Monterrey \\ (I'TESM)-Campus Guaymas, Apdo. Postal 484, \\ Guaymas, Sonora 85400, Mexico \\ JAY BARLOW \\ Southwest Fisheries Science Center, \\ U.S. National Marine Fisheries Service, \\ P.O. Box 271, La Jolla, California 92038, U.S.A. \\ Luis A. Hurtado \\ Jorge TORRE \\ Patricia Cendón ${ }^{2}$ \\ 'LULLY OJEDA \\ CECARENA, ITESM-Campus Guaymas
}

\begin{abstract}
A boat survey was conducted from 5 to 26 June 1993 to estimate the abundance of the Amazon river dolphin (Inia geoffrensis) and the tucuxi (Sotalia fuviatilis) along ca. $120 \mathrm{~km}$ of the Amazon River bordering Colombia, Peru, and Brazil. Two survey methods were used: line transects during $5 \mathrm{~d}$ and strip transects during $15 \mathrm{~d}$. The line transects were used to estimatc the abundance of both species in the main channels of the Amazon at distances greater than $200 \mathrm{~m}$ from river banks and islands, and strip transects were used to estimate abundance in the remainder of the habitat. A total of 29 sightings was obtained using line transects, including 8 of Inia, 15 of Sotalia, and 6 with both species present. The total number of sightings made while using strip transects was 143 , including 78 of Inia, 51 of Sotalia, and 14 with both species present. The distributions of sightings with respect to distance from the nearest bank were not significantly different between the two species. Based on the results from the two methods, we estimate that there are $346(\mathrm{CV}=0.12)$ Inia and $409(\mathrm{CV}=0.13)$ Sotalia in the study area. Overall, the mean group size for Inia was 2.9 individuals and for Sotalia was
\end{abstract}


3.9 individuals. Inia density (dolphin $/ \mathrm{km}^{2}$ ) was highest in tributaries (4.8), followed by areas around islands (2.7) and along main banks (2.0); while Sotalia density was highest in lakes (8.6), followed by areas along main banks (2.8) and around islands (2.0). These are among the highest densities measured to date for any cetacean.

Key words: Amazon dolphins, survey techniques, distribution, abundance, Inia, Sotalia, bufeo colorado, tucuxi, boto, bufeo negro.

Dolphins in riverine environments include some of the most endangered of the world's cetaceans. The principal threats are incidental mortality in fisheries, habitat loss and degradation, directed killing, death in construction, and collision with boats (for a recent review see Leatherwood and Reeves 1994). With a total population estimated as fewer than 100 individuals, perhaps only a few dozen (Leatherwood and Reeves 1994), the baiji (Lipotes vexillifer) is considered the most endangered cetacean. It is likely that this species will become extinct within the next one or two decades. The situation is no more promising for many of the other dolphins of the superfamily Platanistoidea. The bhulan (Platanista minor) and the baiji are listed as "endangered" and the susu ( $P$. gangetica) and the Amazon river dolphin (also known in Spanish as bufeo colorado and in Portuguese as boto) (Inia geoffrensis, hereafter referred to as Inia) as "vulnerable" by the IUCN-The World Conservation Union (Klinowska 1991). The status of the tucuxi (also known in Spanish as bufeo negro) (Sotalia fluviatilis, hereafter referred as Sotalia), a delphinid, is unknown.

In 1986, participants in a workshop on the biology and conservation of platanistoids agreed that the most-needed research was the improvement of survey techniques to estimate the population sizes of these dolphins and to determine trends in their abundance (Perrin and Brownell 1989). To date, however, not much progress has been made in this area (see Reeves and Leatherwood 1994). There are few publications on the abundance of these dolphins, and most of the data come from incidental short-term surveys (Perrin et al. 1989; Reeves et al. 1991, 1993; Reeves and Leatherwood 1995).

Both Inia and Sotalia are distributed in the Amazon and Orinoco basins, the largest river system in the world. Most of what is known about these dolphins in the wild is from work conducted since the early 1980s near Manaus, Brazil (e.g., Best and da Silva 1989, da Silva and Best 1994). Inia is the most geographically widespread of the platanistoid dolphins, being found in parts of Bolivia, Brazil, Colombia, Ecuador, Guyana, Peru, and Venezuela. Sotalia is found in the Amazon-Orinoco River system but also inhabits the sea and can be found in the Caribbean off the coast of Panama and along South America's north and northeastern shores from Colombia to southern Brazil (Borobia et al. 1991).

Few observations have been published on the (relative) abundance of Inia

${ }^{1}$ Present address: \% Water Branch, United Nations Environment Programme, P.O. Box 47074 , Nairobi, Kenya.

2 Present address: $\%$ O. Vidal; see footnote 1. 


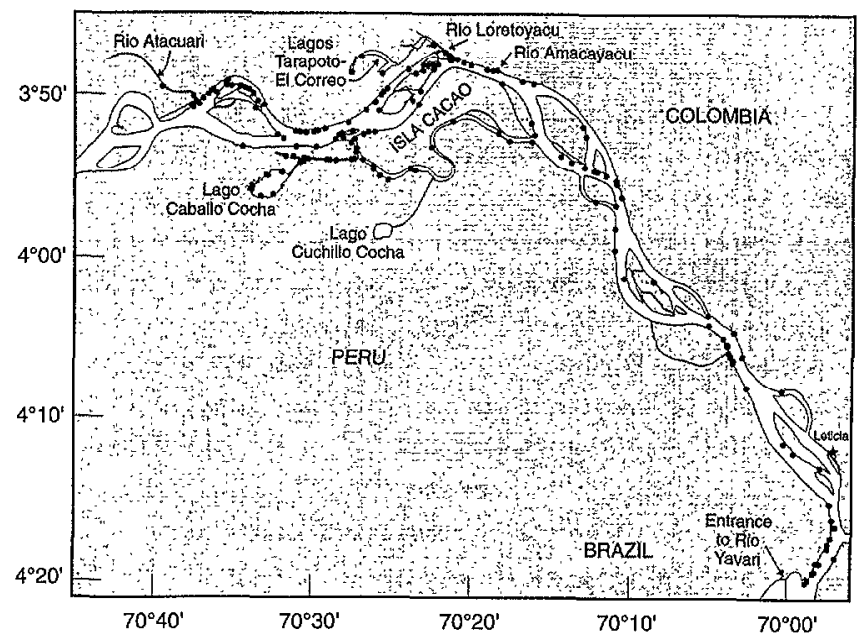

Figure 1. The study area was mapped during the survey period using a GPS, which was connected to give input directly to a laptop computer. A 4-m outboard launch with the GPS and the computer was run at a distance of approximately $10 \mathrm{~m}$ from the banks of all the main channels and islands and some of the associated tributaries. Black dots indicate locations where river dolphins were seen on both strip and line transects.

and/or Sotalia, and most were incidental to other activities and limited to a few sightings on a few days and in small areas (Layne 1958, Kasuya and Kajihara 1974, Pilleri and Gihr 1977, Magnusson et al. 1980, Pilleri et al. 1982 cited in Best and da Silva 1989, Meade and Koehnken 1991, da Silva and Best 1994, Trujillo 1994, Herman et al. 1996, Leatherwood 1996). Only a few of these previous works produced quantitative estimates of density or abundance.

The purposes of this study were (1) to develop methods of survey that are appropriate for use on dolphins in the study area and which potentially could be applicable to other species of river dolphins, (2) to make the first estimates of the abundance of dolphins in the study area, and (3) to establish an initial point for monitoring trends in their abundance through time. This study is part of an overall research project on the ecology and population biology of dolphins in the upper Amazon (Vidal 1994).

\section{Materials and Metilods}

Study area-The study area is about $250 \mathrm{~km}^{2}$ along the $c a .120 \mathrm{~km}$ of the Amazon River, which forms a border between Colombia and Peru, and a small portion of the Peruvian-Brazilian border, in the upper Amazon (Fig. 1). Also, three tributaries (Ríos Atacuari, Loretoyacu, and Amacayacu), two large lake systems (Caballo Cocha and Tarapoto-El Correo), and several narrow channels were surveyed. There are 16 major islands in this area. Many towns and villages are located along the river, with a population of several tens of thousands. 
In the study area, the water level of the Amazon River reaches a maximum in May, coinciding with the peaks of the rainy seasons in the Peruvian and Ecuadorean headwaters and reaches a minimum during July-August (INDERENA 1984). Maximum flood levels in 1993 were higher than normal. The Amazon River ranged between approximately 0.5 and $2 \mathrm{~km}$ in width in the area during our study. Maximum widths of the tributaries ranged between 60 and $200 \mathrm{~m}$. The Amazon is classified (following Meade and Koehnken 1991) as a "whitewater" river, i.e., it is turbid, yellowish brown, and very limited in transparency because of the large load of suspended sediment. During our study, the transparency of the Amazon (measured with a Secchi disk:) was typically less than $25 \mathrm{~cm}$. The tributaries, channels, and lakes are classified as "blackwater," i.e., they are more transparent due to a lack of suspended sediment, but are of a dark color due to high concentrations of dissolved fumic and fulvic acids. Maximum recorded transparency was $1.8 \mathrm{~m}$. White and black waters mix in areas of confluence.

Survey methods-Surveys were conducted from 5 to 26 June 1993, at the beginning of the dry season when flood waters were receding. During the survey, flood waters receded from $c a .0 .5 \mathrm{~m}$ below maximum to $c a .3 .0 \mathrm{~m}$ below maximum. The survey vessel was a $17.5-\mathrm{m}$ river boat (R/B Alcarlety) with a draft of only $1.5 \mathrm{~m}$. A platform was constructed on top of the pilot house for three observers and one data recorder. Observation height was approximately $4.5 \mathrm{~m}$ at eye level for seated observers. Vessel speed varied considerably with the direction and strength of the current, but was typically maintained between 5 and $15 \mathrm{~km} / \mathrm{h}$.

We used line transect and strip transect methods (see Discussion for a justification of using both methods). General procedures were similar to those used in surveys carried out in other studies for marine cetaceans, both pelagic and coastal (for details see, for example, Hammond 1986, Barlow 1988). Here, we briefly describe the changes made to adape those procedures to our study area. ${ }^{3}$ Line transects were used in a zig-zag pattern between opposite banks of the main channels. Strip transects were oriented parallel to the banks of main channels, islands, lakes, and smaller rivers and channels.

Five of the seven observers had previous experience observing river dolphins. Personnel typically rotated among observer, recorder, information-relay, and rest positions. Recorded data included time, position, speed of the vessel, search effort, sighting conditions, sightings, depth, water temperature, and distance to river banks. A transducer and depth sounder (maximum range 36 $\mathrm{m}$ ) were mounted to allow periodic measurements of water depth while the vessel was under way. A portable Geographic Positioning System (GPS) provided continuous information on position, speed, and direction of travel. Water temperature was measured to the nearest $0.1^{\circ} \mathrm{C}$ using a bucket thermometer that had been held underwater at a depth of approximately $30 \mathrm{~cm}$ for a minimum of $30 \mathrm{sec}$. An optical range finder $(46-1,000 \mathrm{~m}$, advertised accuracy

${ }^{3}$ Detailed descriptions of the methods to allow exact replication are found in the cruise report of the survey, available from Vidal. 
of $\pm 9 \mathrm{~m}$ at $300 \mathrm{~m}$ ) was used to estimate distances to the banks of the river and to the location of dolphins. Because of the need to estimate sighting distances rapidly and the difficulty in using the surface ripple left by a surfacing dolphin as a reference, the range finder often could not be used, and the distance from the vessel to the location of dolphins was often estimated by eye. To improve such estimates, observers were frequently asked to make written estimates of the distance to inanimate floating objects in the river and were subsequently told the "true" distance as estimated with the range finder.

The information-relay position was one deck below the observers and next to the pilot house, and the person in that position relayed instructions from the observers to the captain. The following data on sighting conditions were recorded every 10 min: direction of travel, speed, water depth, water temperature, presence of rain or fog within one kilometer, percent overcast, and a relative measure of the effect of sun glare, wind, and water currents on sighting conditions. Time and position were recorded when searching effort began and ended. Only those sightings made while "on effort" were recorded as "sightings." Only sightings made by one of the three "on duty" observers were recorded as "sightings." All other personnel were required not to mention dolphins that they had seen until the animals had passed well out of the observers' fields of view; these sightings were not systematically obtained and were only recorded as "comments."

Line transects - Line transects were conducted during five days (5 and 8-11 June). Five observers rotated among three observation positions, one data recorder position, and one rest position. The information-relay position was occupied all day by the same person, who gave turning instructions to the captain. Observers at all three observer positions searched primarily by "naked eye" and intermittently with $7 \times$ or $8 \times$ binoculars. The two outside observers searched from $0^{\circ}$ to $90^{\circ}$ on their respective sides of the vessel, and the center observer searched from $45^{\circ}$ right to $45^{\circ}$ left.

Truly random or systematic transect lines were deemed infeasible due to the complex physiography and inexperience of the captain in using electronic navigation aids. Instead, transect lines were established by selecting an arbitrary starting point and applying a simple turning rule. The vessel started toward a point on the opposite bank that was at a $45^{\circ}$ angle to the adjacent bank and continued across the river (compensating for river flow) to within approximately $50 \mathrm{~m}$ of the chosen point (or less close if navigation hazards were present). A compass was used to determine the angles. A new point was then chosen on the opposite bank at a $45^{\circ}$ angle to the adjacent bank and the captain was directed to head for the new point. The same turning rule was applied whether the transect line intersected one of the main banks of the river or onc of the islands. A total of 96 transccts werc surveyed in this manner, beginning with transects in the southeast and working towards the northwest.

When a dolphin was sighted, search effort was discontinued and observers concentrated on recording information about that sighting. Sighting information included a consecutive sighting number; the observer who made the sighting; whether that person was searching with binoculars or "naked eyes" 
when the dolphins were first seen; the initial angle relative to the bow of the boat and distance from the boat to the dolphins; and best, maximum, and minimum estimates of the number of each species present. The vessel was directed to proceed to the location where the animals were first seen to measure position, depth, water temperature, and distances to the nearest banks to the right and left of the transect line. After this, the boat returned to the original position to continue the transect.

Strip transects - Strip transects were conducted from 12 to 26 June. They were carried out at a distance of $100 \mathrm{~m}$ from the banks of the Amazon River, around all but three of its 16 major islands, and in two lake systems associated with that river. Strip transects were also conducted from the center of several minor channels of the Amazon River and in several tributaries. In cases where small islets (called playas) were found close to the main river bank or close to an island, the transect lines went outside of the playa (inside was often dangerously shallow, usually less than $2 \mathrm{~m}$ ).

Routine data collected every $10 \mathrm{~min}$ during strip transects also included nearest distance to shore on the left and on the right of the transect line. During the strip transect survey, six or seven observers rotated among three observation positions, the data recorder position, and the information-relay position. Observers at the right and left positions searched primarily by "naked eye" between $0^{\circ}$ and $90^{\circ}$ on their respective sides, and the center observer searched almost exclusively with $7 \times$ or $8 \times$ binoculars between $45^{\circ}$ right and $45^{\circ}$ left. The center observer was instructed to search at a greater distance to detect dolphins that might avoid detection by remaining submerged, entering the flooded forest, or passing under floating vegetation when the vessel approached closer.

Strip width was defined post facto (see Abundance Estimation below). Observers did not know at the time of the survey what distance would define the outer margin of the survey strip. The position of the vessel depended on the width of the waterway being surveyed. If the waterway was a channel or river less than $200 \mathrm{~m}$ wide, the vessel passed down the center of the channel. If the waterway was a lake or a channel wider than $300 \mathrm{~m}$, the vessel conducted transects at a distance of $100 \mathrm{~m}$ from each bank, and all dolphins between the nearer bank and the center of the waterway were counted. Channels of intermediate width $(200-300 \mathrm{~m})$ were typically treated as wide channels. Occasionally, when conducting transects at $100 \mathrm{~m}$ from one bank, dolphins would be seen that were closer to the opposite bank. Such sightings were not included in the data, because they were outside the defined strip width and to include them would probably have resulted in double-counting. If there was a question about which bank they were closer to, the vessel was directed to the location of the animals when they were first seen, and the distance was measured to both banks using an optical range finder.

Each island transect consisted of the complete circumnavigation of one island (except the large Isla Cacao, which had two transects). On the first island transects, we noticed that dolphins appeared concentrated at the extreme upcurrent or downcurrent points of islands, so most island transects were started 
away from these points to minimize confusion and possible double-counting of the same animals at the beginning and end of a circular transect.

Sigbtings-Sightings of ten consisted of loosely associated dolphins (we called them "aggregations") which are not like the cohesive schools of most marine dolphins. Groups and subgroups within a "sighting" sometimes showed cohesive social behavior, especially the female/calf pairs. A group was defined (following Shane 1990) as any number of dolphins observed in apparent association, moving in the same direction, and often-but not always-engaged in the same activity. An aggregation consisted of several groups. Both Inia and Sotalia were often found in the same general area but did not appear to be interacting. There was considerable uncertainty and subjectivity in defining what constituted a "sighting." As we used the term, a sighting refers to all the animals in the immediate vicinity of an animal that had been sighted. Typically we counted all the dolphins visible at the location where the first dolphin was secn. If all the dolphins in the area could not be casily counted from that location, the vessel was moved closer to the dolphins. Often the vessel had to be moved several times to get good estimates of all of the subgroups. When the direction of the survey vessel was the same as that of the current, the boat was often put in neutral and allowed to drift until we approached the dolphins. The size of an area included within a "sighting" varied, but typically was less than $200 \mathrm{~m}$ along a shoreline and was almost always less than $500 \mathrm{~m}$.

Estimating the number of freshwater dolphins present in an area is particularly challenging. Typically, this number was estimated by direct counting of the number of distinct surfacings. However, because all animals are seldom at the surface at the same time, this counting procedure requires judgement as to whether two surfacings are likely to have been by the same or different individuals. All available personnel (not just the three observers on duty at the time of the sighting) aided in making a consensus estimate of the number of animals present. The more experienced river dolphin researchers tended to take the lead in abundance estimation. The counting procedure was often facilitated by using scars, notches, and unique color patterns that many of the dolphins (particularly Inia) have, to determine whether two surfacings were by the same animal (see Trujillo 1994). A maximum of $15 \mathrm{~min}$ was allowed for counting dolphins on a given sighting. This was long enough to get a good count, but not so long that movement of animals into and out of the area became a problem.

Abundance estimations: line transects-The abundance of Inia and Sotalia in the main channels of the Amazon (at distances of greater than $200 \mathrm{~m}$ from the nearest bank or island) was estimated from the zig-zag line transects. The basic line-transect equation for estimating abundance, $N$, for grouped animals using line transect is given by:

$$
N=\frac{\operatorname{AnSf}(0)}{2 \operatorname{Lg}(0)}
$$

where 


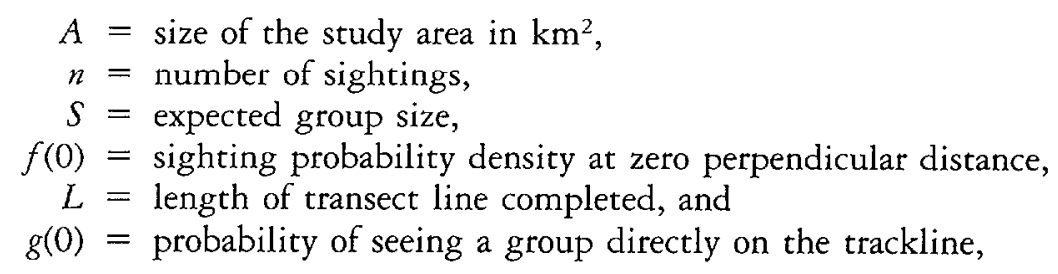

(Buckland et al. 1993). The size of the study area, A, was estimated as the total water area between the main banks of the Amazon in our study area (Fig. 1) minus the land atea of the islands and minus the areas covered by strip transects in the main channels. The number of sightings, $n$, and the length of transects, $\mathrm{L}$, were limited to sightings and transect segments that were farther than $200 \mathrm{~m}$ from the nearest river bank or island. There was no significant correlation between the logarithm of group size and the sighting probability function $g(x)\left(r^{2}=0.06, P=0.59\right)$ (Buckland et al. 1993), so expected group size was estimated as a simple mean group size. The parameter $f(0)$ (or 1/effective half-strip width) was estimated using both hazard rate and half-normal key functions with and without cosine adjustment terms using the program DISTANCE (Laake $e t$ al. 1993), and the best model fit was chosen on the basis of minimizing the Akaike Information Criterion (AIC). In estimating $f(0)$, all sightings of both species were pooled (including some that were closer than $200 \mathrm{~m}$ from a bank) for those effort segments when the vessel was at least $200 \mathrm{~m}$ from a bank; this increased the sample size from 10 to 16 and improved the precision in estimating $f(0)$. Perpendicular distances were not grouped when estimating $f(0)$ but were truncated at $450 \mathrm{~m}$ (eliminating only one sighting). The probability of seeing a group directly on the trackline $[g(0)]$ is assumed to be 1.0 (but see Discussion).

Abundance estimation: strip transects-The abundance of both species within $200 \mathrm{~m}$ of riverbanks and islands was estimated using strip-transect methods. Strip widths were defined as either (1) $200 \mathrm{~m}$ (in channels wider than 400 $\mathrm{m}),(2)$ the actual width of the channel (in channels less than $200 \mathrm{~m}$ wide), or (3) half the width of the channel (in channels between $200-400 \mathrm{~m}$ wide). Of the 118 sightings made in channels wider than $200 \mathrm{~m}$, only 17 were excluded for being outside the defined strip. For purposes of abundance estimation, we assume that all animals within the defined strip are counted (but see Discussion).

Prior to the survey, 44 strip transects were defined and were stratified based on the type of habitat being surveyed: (1) along banks in the main channels of the Amazon River, (2) around islands in the main channels of the Amazon River, (3) in the small canals passing through those islands, (4) in smaller tributaries and canals of the Amazon River, and (5) in lakes. Virtually all of the river bank habitat (Type 1) was surveyed. Two of the islands and half of another (Type 2 habitat) were not surveyed due to lack of time. Most of the canals within islands (Type 3 habitat) were not surveyed because the canals were not navigable with our vessel. Some of the smaller canals (Type 4 habitat), such as the one leading to Lago Cuchillo Cocha, were also not navigable. One 


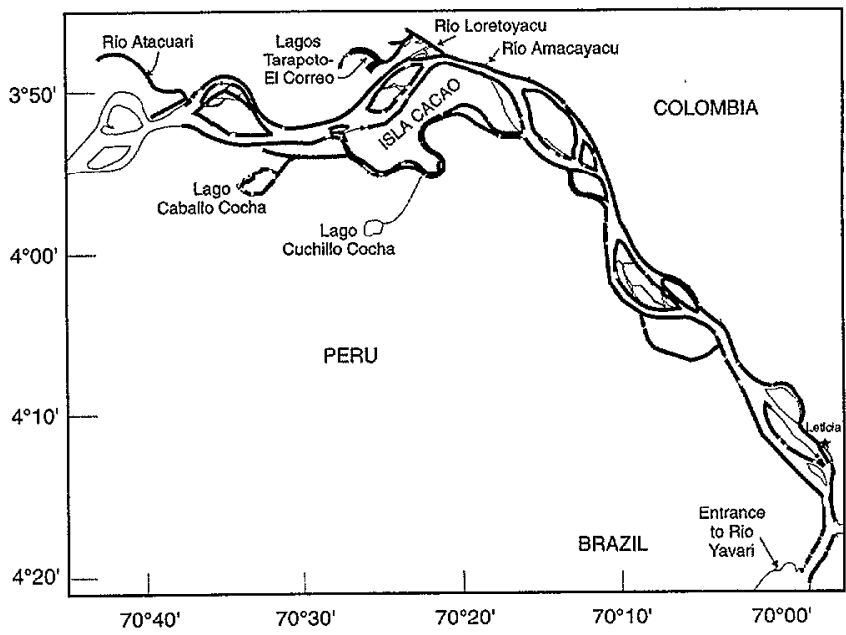

Figure 2. Bold lines indicate strip transects that were surveyed. Strip transects were conducted at a distance of approximately $100 \mathrm{~m}$ from the bank in channels wider than $300 \mathrm{~m}$ and down the center of smaller channels.

of the three lake habitats (Cuchillo Cocha) (Type 5 habitat) within our study area could not be accessed. Overall, the majority of defined transects were surveyed (Fig. 2).

The abundance of dolphins $\left(N_{i}\right)$ within a habitat stratum (i) was estimated as the product of the mean density of individuals $\left(D_{i}\right)$ times the total area in defined transect strips $\left(A_{i}\right)$. The mean density of individuals $\left(D_{i}\right)$ was estimated as the mean sighting tate $\left(R_{i}\right.$, individuals seen per linear kilometer of transect completed) divided by the mean strip width ( $W_{i}$, calculated from the distances to left and right banks which were recorded every $10 \mathrm{~min}$, using the stripwidth definitions given above):

$$
N_{i}=D_{i} \cdot A_{i}=\frac{R_{i}}{W_{i}} \cdot A_{i} .
$$

The mean sighting rate $\left(R_{i}\right)$ was estimated as an unweighted average of the sighting rates of all completed transects; for transects that were replicated, the mean of the replicates was used in this average. The mean strip width in the unnavigable, unsurveyed canals was estimated to be $50 \mathrm{~m}$ based on reconnaissance trips taken by small launch. The total abundance of dolphins within the strip transects is the sum of the estimates for the five habitat types.

The variance of the strip-transect estimates of abundance was calculated using a modification of the method described by Seber (1982, p. 23-24) for a randomly selected subset of $s$ transects (quadrats) from a total of $S$ predefined transects. Let $p$ equal the fraction of the total area that was surveyed. The variance of the population estimate is given by:

$$
\operatorname{Var}\left(N_{i}\right)=\frac{A_{i}^{2}}{W_{i}^{2}} \frac{\operatorname{Var}\left(R_{i}\right)}{s_{i}}\left(1-p_{i}\right)
$$




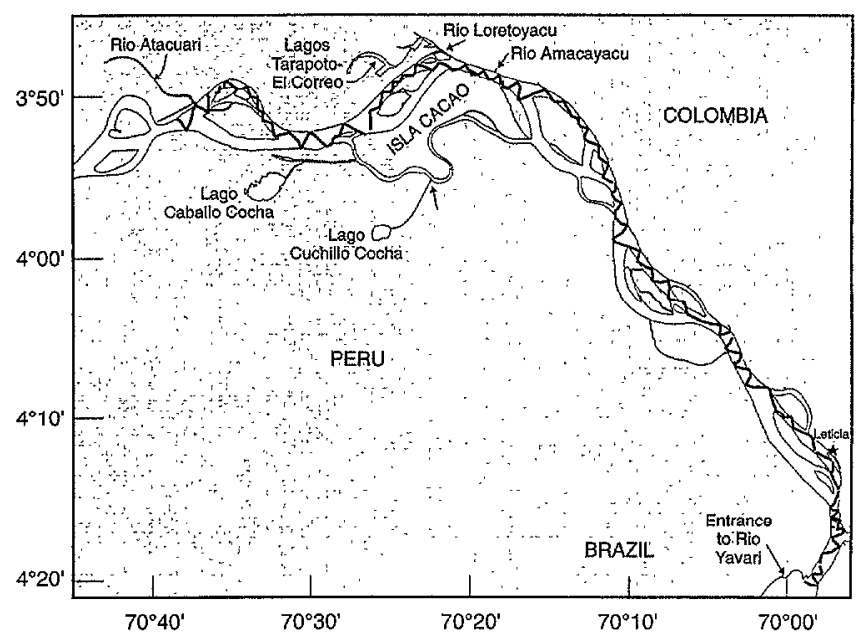

Figure 3. Bold lines indicate line transects that were surveyed in the main channels of the Amazon River. Transects followed a zig-zag course from one bank to the other at a $45^{\circ}$ angle to the current flow.

Dolphins are not assumed to be randomly distributed; therefore, within a stratum ( $i)$ the variance in the sighting tate is estimated empirically from the average sighting rates $\left(r_{i, j}\right)$ on individual transects $(j)$ as:

$$
\operatorname{Var}\left(R_{i}\right)=\sum_{j=1}^{s} \frac{\left(r_{i, j}-R_{i}\right)^{2}}{(s-1)} .
$$

Only one transect was completed in Type 3 habitat and only two were completed in Type 5 habitat, so the above formula was not used to calculate the variance in sighting tate. For those two cases, the variance in the sightirg rate was estimated by assuming that the number of sightings follows an inflated poisson distribution with a variance equal to twice the number of sightings (this approximation gave similar results to the empirical estimate for the other three habitat types). The variance of the total abundance estimate $N$ was calculated as the sum of the variances for the habitat types.

\section{RESULTS}

Line transects-A series of zig-zag transect lines totalling $161 \mathrm{~km}$ was surveyed from the entrance of a channel of the Río Yavari (just south of Tabatinga, Brazil), on the Peruvian-Brazilian border, to just west of the mouth of the Río Atacuari in Peru (Fig. 3). This method was limited to the main channels of the Amazon River. We had 29 sightings: 8 of Inia, 15 of Sotalia, and 6 with both species present. Only 34\% of these sightings ( 3 sightings of Inia, 5 of Sotalia, and 2 with both) and $60 \%$ of searching effort $(96 \mathrm{~km})$ were at distances greater than $200 \mathrm{~m}$ from banks or islands and are, therefore, included in estimating the sighting rate, $\mathrm{n} / \mathrm{L}$, for line-transect estimates of dolphin density (Table 1). 
Table 1. Results of line-transect surveys for Inia and Sotalia and estimates of their density and abundance for the stratum which includes waters greater than $200 \mathrm{~m}$ from the nearest river bank or island in the main channels of the Amazon River. Groups containing both species were included in the tally of sightings for both species. The effective half-strip width $(1 / f(0))$ was estimated for both species pooled.

\begin{tabular}{|c|c|c|c|c|c|c|c|c|c|c|c|}
\hline pecies & $\begin{array}{l}\text { Num- } \\
\text { bet } \\
\text { sight- } \\
\text { s ings }\end{array}$ & $\begin{array}{c}\text { Total } \\
\text { dis- } \\
\text { tance } \\
\text { sur- } \\
\text { veyed } \\
(\mathrm{km})\end{array}$ & $\begin{array}{c}\text { Mean } \\
\text { group } \\
\text { size }\end{array}$ & $\begin{array}{l}\text { Mean } \\
\text { sight- } \\
\text { ing } \\
\text { rate } \\
\text { (Dol- } \\
\text { phins } \\
\mathrm{km}^{-1} \text { ) }\end{array}$ & $\begin{array}{l} \\
\mathrm{CV} \\
\text { sight- } \\
\text { ing } \\
\text { rate }\end{array}$ & $\begin{array}{l}\text { Effec- } \\
\text { tive } \\
\text { half- } \\
\text { strip } \\
\text { width } \\
(\mathrm{km})\end{array}$ & $\begin{array}{c}\text { CV } \\
\text { ESW }\end{array}$ & $\begin{array}{c}\text { Study } \\
\text { area } \\
\left(\mathrm{km}^{2}\right)\end{array}$ & $\begin{array}{c}\text { Dol- } \\
\text { phin } \\
\text { density } \\
\left(\mathrm{km}^{2}\right)\end{array}$ & Abund. & $\begin{array}{c}\text { CV } \\
\text { Abund. }\end{array}$ \\
\hline & 5 & & 40 & & & & & & & & 04 \\
\hline otalia & 7 & 95.63 & 6.00 & 0.439 & 0.27 & 0.245 & 0.19 & 170.1 & 0.895 & 152 & 0.33 \\
\hline
\end{tabular}

Because the 10 sightings that were greater than $200 \mathrm{~m}$ from the banks are not adequate to estimate the $f(0)$ parameter, we pooled sightings of both species and all sightings that were made while searching at distances greater than $200 \mathrm{~m}$ from any bank (including 6 sightings that were located within $200 \mathrm{~m}$ of a bank, but excluding 13 sightings that were made at searching distances less than $200 \mathrm{~m}$ from a bank). The sighting probability distribution is fairly flat out to approximately $100 \mathrm{~m}$ perpendicular distance (Fig. 4). The

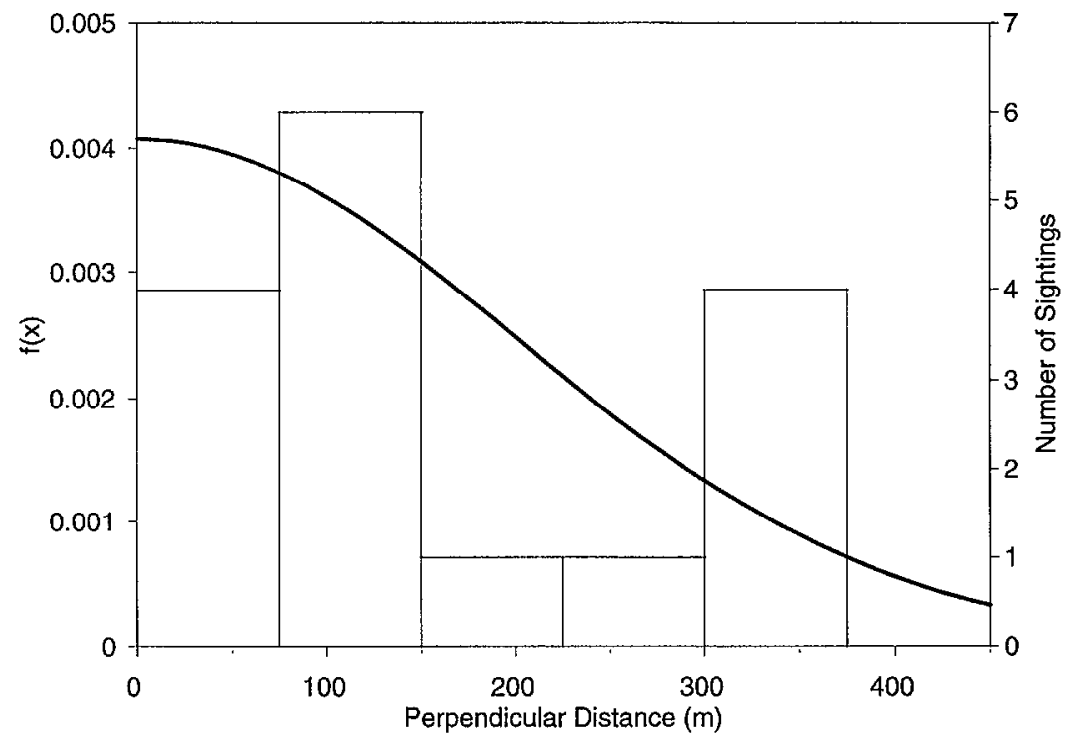

Figure 4. Histogram represents the distribution of perpendicular distances to sightings made from zig-zag line transects in the main channels of the Amazon when the vessel was greater than $200 \mathrm{~m}$ from the nearest island or river bank. Continuous curve represents probability density function based on maximum likelihood fit of half-normal model to the perpendicular distance data. 


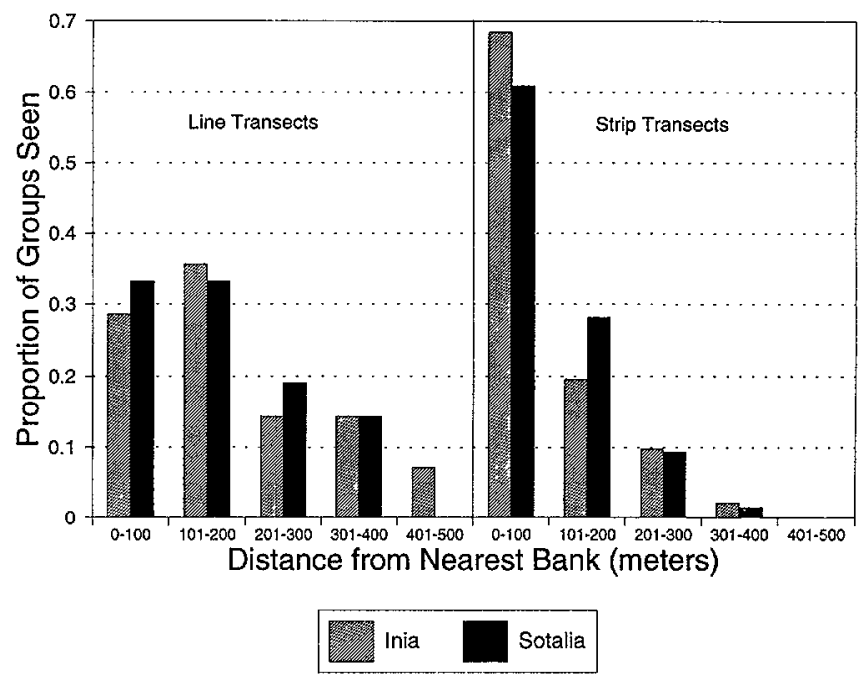

Figure 5. Distributions of distances from the nearest river bank for sighting of Inia and Sotalia made on line-transect and strip-transect surveys in the main channels of the Amazon River. Groups containing both species are counted twice, once for each species.

best-fit sighting probability model was achieved with a half-normal key function and no cosine adjustment terms (Fig. 4) and gives an estimate of an effective half-strip width of $245 \mathrm{~m}$ (Table 1 ).

The distributions of sightings with respect to distance from the nearest bank (Fig. 5) were not significantly different between the two species [Kolmogorov/Sminov $(\mathrm{K} / \mathrm{S})$ test excluding groups with both species, $P=0.7$ ]

Strip transects-Strip transects covered $616 \mathrm{~km}$ (Fig. 2). The total number of sightings was 143, including 78 sightings of Inia, 51 of Sotalia, and 14 with both species present. Due to time limitations and navigational constraints, not all of the defined strip transects were completed. Transect lines 15 and 16 were replicated five and three times, respectively, to estimate the variance that might be expected in replicate surveys. Other transect lines (such as tributaries) were replicated twice in the same day because the vessel was required to retrace its path.

The distributions of sightings with respect to distance from the nearest bank in the main channels of the Amazon River (Fig. 5) were not significantly different between the two species (K/S test excluding groups with both species, $P=0.5$ ).

Abundance estimation - The line-transect estimates of dolphin abundance for the center of the main channels ( $>200 \mathrm{~m}$ from banks) were $98(\mathrm{CV}=0.41)$ Inia and $152(\mathrm{CV}=0.33)$ Sotalia (Table 1). The strip-transect estimates for the remainder of their habitat were similar for both species: $248(\mathrm{CV}=0.05)$ Inia and $257(\mathrm{CV}=0.07)$ Sotalia (Table 2). The combined estimates for these two strata were $346(\mathrm{CV}=0.12)$ Inia and $409(\mathrm{CV}=0.13)$ Sotalia (coefficients of variation are based on additivity of variances). 
Table 2. Results of strip-transect surveys for Inia and Sotalia and estimates of their density and abundance for the stratum which includes lakes, smaller tributaries and canals, and waters closer than $200 \mathrm{~m}$ from the nearest river bank or island in the main channels of the Amazon River. Groups containing both species were included in the tally of sightings for both species. "Unsurveyed Areas" refer to defined strip transects that were not surveyed due to lack of accessibility or lack of time and do not include areas of the main channels that were greater than $200 \mathrm{~m}$ from a river bank or island.

\begin{tabular}{|c|c|c|c|c|c|c|c|c|c|c|c|c|c|c|}
\hline \multirow[b]{2}{*}{$\begin{array}{l}\text { Species } \\
\text { habitat }\end{array}$} & \multirow[b]{2}{*}{$\begin{array}{l}\text { Num- } \\
\text { ber } \\
\text { sight- } \\
\text { ings }\end{array}$} & \multirow[b]{2}{*}{$\begin{array}{c}\text { Total } \\
\text { distance } \\
\text { surveyed } \\
(\mathrm{km})\end{array}$} & \multirow[b]{2}{*}{$\begin{array}{l}\text { Mean } \\
\text { group } \\
\text { size }\end{array}$} & \multirow[b]{2}{*}{$\begin{array}{l}\text { Mean } \\
\text { sighting } \\
\text { rate } \\
\text { (Dol- } \\
\text { phins } \\
\mathrm{km}^{-1} \text { ) }\end{array}$} & \multirow[b]{2}{*}{$\begin{array}{c}\mathrm{CV} \\
\text { sighting } \\
\text { rate }\end{array}$} & \multicolumn{3}{|c|}{ Surveyed areas } & \multicolumn{3}{|c|}{ Unsurveyed areas } & \multirow[b]{2}{*}{$\begin{array}{c}\text { Dolphin } \\
\text { density } \\
\left(\mathrm{km}^{-2}\right)\end{array}$} & \multirow[b]{2}{*}{$\begin{array}{l}\text { Abun- } \\
\text { dance }\end{array}$} & \multirow[b]{2}{*}{$\begin{array}{l}\mathrm{CV} \\
\text { abun- } \\
\text { dance }\end{array}$} \\
\hline & & & & & & $\begin{array}{c}\text { Total } \\
\text { length } \\
\text { of } \\
\text { transects } \\
(\mathrm{km})\end{array}$ & $\begin{array}{l}\text { Average } \\
\text { strip } \\
\text { width } \\
(\mathrm{km})\end{array}$ & $\begin{array}{c}\text { Area } \\
\left(\mathrm{km}^{2}\right)\end{array}$ & $\begin{array}{l}\text { Total } \\
\text { length } \\
\text { of } \\
\text { tran- } \\
\text { sects } \\
(\mathrm{km}) \\
\end{array}$ & $\begin{array}{c}\text { Average } \\
\text { strip } \\
\text { width } \\
(\mathrm{km})\end{array}$ & $\begin{array}{c}\text { Area } \\
\left(\mathrm{km}^{2}\right)\end{array}$ & & & \\
\hline \multicolumn{15}{|l|}{ Inia } \\
\hline Main banks & 42 & 317.7 & 2.4 & 0.40 & 0.38 & 219.6 & 0.198 & 43.5 & 0.0 & & 0.0 & 2.02 & 88 & 0.00 \\
\hline Islands & 31 & 186.1 & 3.1 & 0.52 & 0.18 & 186.1 & 0.193 & 35.9 & 27.8 & 0.193 & 5.4 & 2.69 & 111 & 0.06 \\
\hline Is. canals & 1 & 6.3 & 3.0 & 0.48 & 1.41 & 6.3 & 0.163 & 1.0 & 38.2 & 0.050 & 1.9 & 2.93 & 9 & 1.14 \\
\hline Tributaries & 15 & 85.0 & 4.1 & 0.60 & 0.37 & 50.0 & 0.125 & 6.3 & 16.6 & 0.050 & 0.8 & 4.80 & 34 & 0.13 \\
\hline Lakes & 3 & 21.3 & 2.0 & 0.29 & 0.82 & 15.4 & 0.189 & 2.9 & 6.8 & 0.189 & 1.3 & 1.53 & 6 & 0.45 \\
\hline Overall & 92 & 616.3 & 2.9 & 0.43 & & 477.4 & & 89.6 & 89.4 & & 9.4 & & 248 & 0.05 \\
\hline \multicolumn{15}{|l|}{ Sotalia } \\
\hline Main banks & 28 & 317.7 & 4.5 & 0.55 & 0.40 & 219.6 & 0.198 & 43.5 & 0.0 & & 0.0 & 2.78 & 121 & 0.00 \\
\hline Islands & 18 & 186.1 & 3.6 & 0.39 & 0.51 & 186.1 & 0.193 & 35.9 & 27.8 & 0.193 & 5.4 & 2.02 & 83 & 0.18 \\
\hline Is. canals & 1 & 6.3 & 1.0 & 0.16 & 1.41 & 6.3 & 0.163 & 1.0 & 38.2 & 0.050 & 1.9 & 0.97 & 3 & 1.14 \\
\hline Tributaries & 10 & 85.0 & 2.5 & 0.24 & 0.38 & 50.0 & 0.125 & 6.3 & 16.6 & 0.050 & 0.8 & 1.92 & 14 & 0.13 \\
\hline Lakes & 8 & 21.3 & 4.1 & 1.62 & 0.50 & 15.4 & 0.189 & 2.9 & 6.8 & 0.189 & 1.3 & 8.57 & 36 & 0.28 \\
\hline Overall & 65 & 616.3 & 3.9 & 0.41 & & 477.4 & & 89.6 & 89.4 & & 9.4 & & 257 & 0.07 \\
\hline
\end{tabular}


Dolphin densities-Inia densities based on the above estimates of total abundance were highcst in the tributaries ( 4.8 dolphins $/ \mathrm{km}^{2}$ ), followed by areas around islands (2.7) and along main banks (2.0), and were lowest in the middle of large channels (0.6). Sotalia densities were highest in lakes (8.6), followed by main banks (2.8) and areas around islands (2.0), and were lowest in the middle of large channels (0.9) and in small canals passing through islands (1.0). Most sightings of both species ( $80 \%$ of Inia, $70 \%$ of Sotalia) were along the main banks and around large islands. Overall, the mean group size for Inia was 2.9 individuals and for Sotalia was 3.9 individuals.

\section{Discussion}

Survey design-This study was designed to explore both line-transect and strip-transect approaches to estimating river dolphin abundance. Prior to this study, neither approach had been used rigorously to estimate dolphin abundance in rivers ${ }^{4}$, and, therefore, any approach we used was experimental. We originally planned to use zig-zag line transects for two passes along the entire length of the main channcls, and wc planned to estimate dolphin abundance from these transects for the entire width of the river.

After one pass through the study area, a serious deficiency was apparent in the zig-zag line-transect surveys. 'The majority of sightings (66\%) were within $200 \mathrm{~m}$ of the river banks and islands and were therefore concentrated near the apexes of the inbound and outbound legs of effort. This creates an area of overlap between the inbound and outbound transects which poses a problem in analysis of line-transect data, especially when (as in this case) the area of overlap is large relative to the distance at which animals can be sighted and the fraction of animals there is high. In our analyses we dealt with the problem of overlap areas by not using sightings and effort within $200 \mathrm{~m}$ of the banks or islands. This reduced the sample size considerably and resulted in relatively imprecise estimates of abundance for the mid-channel areas (Table 1).

Our decision to switch from line transects to strip transects earlier than planned (after only one pass through the study area) was based on this and on a variety of other factors. Navigation of zig-zag lines proved to be extremely difficult given the strong currents and the captain's lack of familiarity with electronic navigation aids. Because of these navigation difficulties, we were concerned about the future replicability of our transect lines and therefore their value for monitoring trends in abundance over time. We were also concerned about whether sufficient sightings would be collected to make a precise estimate of dolphin abundance. We reasoned that if the majority of dolphins are close to the banks we could increase our sighting rates (and therefore the precision of our abundance estimates) by concentrating our survey efforts in those areas. As it turned out, however, the sighting rates are not as different between the line transects and strip transects as we imagined they might be

${ }^{4}$ Subsequently, Leatherwood (1996) used both methods to estimate the abundance of river dolphins in the upper Amazon Basin, Peru. 
[mean dolphin sighting rates for line transects were $0.28 \mathrm{~km}^{-1}$ for Inia and $0.44 \mathrm{~km}^{-1}$ for Sotalia (Table 1), and weighted mean sighting rates for strip transects along main banks and islands were $0.44 \mathrm{~km}^{-1}$ for Inia and 0.49 $\mathrm{km}^{-1}$ for Sotalia (Table 2)]. In hindsight, the precision of our overall abundance estimates would have been improved by some additional line-transect effort in the mid-channel areas.

Abundance estimation-In general, strip transects worked better than line transects in our study. It was far easier to direct the vessel on a path parallel to the bank than it was to direct the vessel on zig-zag transect lines. The primary assumption of strip-transect surveys is that all individuals within the transect strip are counted. This assumption is certainly not met for freshwater dolphins. The line-transect data show that sighting probabilities are relatively constant out to $100 \mathrm{~m}$ from the trackline (Fig. 4); therefore, few animals should be missed if they are within our defined strips and if they are visible at the surface. A much greater problem with both strip and line transects is missing dolphins because they do not surface (or do so cryptically) and avoid vessels; such dolphins are not available to be seen. This problem is particularly acute for Inia, which we saw move under floating vegetation when a vessel was approaching and which commonly enter the flooded forest (this was observed during the present cruise and also during extensive field observations by some of the authors; Vidal, unpublished data). We tried to minimize the number missed by using multiple observers and by searching far in front of the vessel with binoculars. Even so, off-duty observers occasionally saw dolphins that were obviously missed by the on-duty observers. Animals that are far from the transect line are especially likely to be missed, but animals that are close to the transect line are also missed. We did not collect sufficient information to quantify the fraction missed. Therefore, both strip- and linetransect estimates of dolphin abundance have a negative bias. Our perception is, however, that this bias is not likely to change through time (assuming that future surveys are done using the same type of survey vessel and the same methods). Additional work is needed to quantify this bias.

The methods we used to estimate the variance associated with our abundance estimates do not account for all sources of sampling variation and the resulting coefficients of variation in the abundance estimates are likely to be too small. The selection of transects to be surveyed was not entirely random; howcver, this cffect is likely to be small becausc most transects werc surveycd. More importantly, because we could not conduct an instantaneous survey of all transects, the movement of animals between transects would inflate the variance of our estimate and would introduce covariance between adjacent transects. This would be difficult to model statistically, but if the movements are random, this should bias only our variance and not our abundance estimates. Also, we treated the number of individuals in each group as if it were known without error. In fact, considerable subjectivity exists in estimating group size for freshwater dolphins, which would also result in an underestimate of the true variance. A worst-case variance of the abundance estimate was calculated by assuming that the empirical estimate of variance in the 
sighting rate (Equation 4) applies to transects that were surveyed, as well as to transects that were not surveyed (essentially setting $p_{i}=0$ in Equation 3). Using this worst-case variance, the coefficients of variation for the strip-transect abundance estimates increase from 0.05 to 0.17 for Inia and from 0.07 to 0.26 for Sotalia. The true uncertainty in our abundance estimates probably lies within these ranges.

Dolpbin densities-Densities of Inia and Sotalia in our study area (Table 2) and in Peru's upper Amazon Basin (Leatherwood 1996, tables 17-19) are typically between 1 and 10 individuals $/ \mathrm{km}^{2}$ and are among the highest densities measured for any cetacean. For comparison, harbor porpoises ( $P$ hocoena phocoena) in high-density areas off Oregon and Washington, are 1-3 individuals $/ \mathrm{km}^{2}$ (Barlow 1988), and short-beaked common dolphins (Delphinits delphis) off California, are 0.3 individuals $/ \mathrm{km}^{2}$ (Barlow 1995). For our study area, we believe that this high density is likely the result of special physiographical and hydrological characteristics, which favor and maintain a high diversity and abundance of fishes (the main food of the dolphins) but which also offer to the dolphins suitable areas for reproduction, resting, etc. It is important to bear this in mind and to be caurious before making extrapolations of our abundance estimates to other areas of the Amazon where these dolphins occur.

Extensive field observations conducted by some of us in the study area from March to December 1993 (Vidal, unpublished data) demonstrated that although dolphins of both species are commonly found within most of this area, they concentrate in certain zones. These zones are characterized by having (1) a confluence of the Amazon River with either a tributary or a large channel resulting in a mixture of "white" and "black" waters, (2) downstream ends of islands, and (3) a lake. Feeding behavior of both Inia and Sotalia was much more commonly seen in these turbulent areas of confluence than in any other habitat. Similar observations were reported by da Silva (1983) and da Silva and Best (1994) near Manaus, Brazil, and we agree with their conclusion that dolphins congregate in these areas because of the abundance of fishes which are easily captured. This is also supported by the fact that most human fishing activities take place in these areas of confluence. Layne (1958) observed a definite tendency for both species to move into the lakes and associated channels during late afternoon.

\section{RECOMMENDATIONS}

Dolphins that are missed-The greatest shortcoming of the strip-transect method is violation of the assumption that all animals are seen within the strip. Additional research is needed to better estimate the fraction of arimals that are missed. One strategy for estimating this fraction would be to have two independent observer platforms, one with three observers looking forward and one with one or more observers looking backwards. The forward-looking observers would behave exactly as they did on this survey, but the backwardlooking observers would record only sightings that were obviously missed by the forward-looking observers. 
Scientific personnel-Personnel participating as observers in future cruises should be trained in the field by observing both species of dolphins for at least several weeks before starting the cruises. This would allow comparison with the data we have obtained in this study. At least some of the observers should have several months of experience estimating group sizes of river dolphins.

Survey methods-Future surveys of river dolphins in wide channels might benefit from using a hybrid of our survey design-line transects oriented parallel to the rivers course at varying distances from the bank (say $100 \mathrm{~m}$, $200 \mathrm{~m}$, and $400 \mathrm{~m}$, depending on the width of the river). This approach would allow the simultaneous estimation of sighting probabilities as functions of both distance from the trackline and distance from the bank. (A single transect, parallel to the bank, is not sufficient to allow this.) Such an approach is likely to be more efficient than our zig-zag line-transect design because it could concentrate effort where more of the dolphins are, would avoid the problem of concentrating effort in narrow channels and at apexes of the zigzags, would be easier to implement, and would be easier to replicate. This method would, however, require a detailed map of the river that could be used to estimate the river's surface area as a function of distance from the nearest point of land.

Future surveys - The present study established an initial point for monitoring trends in abundance of Inia and Sotalia through time in the study area. However, additional surveys should be conducted (ideally one or two per year) to allow further refining of the methods, and to monitor the population status of these dolphins in this region. Additional recommendations are given in the cruise report ${ }^{3}$.

\section{ACKNOWLEDGMENTS}

The United Nations Environment Programme funded the overall project of which this study is part. Housing and logistical support in the field were kindly provided by the government of Colombia through the Instituto Nacional de los Recursos Naturales Renovables y del Ambiente (INDERENA), now part of the Ministry of the Environment. We thank Carlos Castaño, Bernardo Ortíz von Halle, Antonio Villa, Martha Rojas, José Yunis, Marcela Cano, Nelson Betancourt and, especially, Oscar Tamayo (Jefe, Amacayacu Natural National Park) of INDERENA for their help and support. We also thank Julio A. Ocampo (the Peruvian consul in Leticia), José Becerra Catachunga and Ever Sinarahgua Solano (our field assistants), Rodolfo and his staff at the Amacayacu, Juan Carlos Cortez (who participated as an observer), and Roberto Rodríguez ("Grano de Pólvora") and the crew of the Alcarlety. Without the help and support of Angel, Michel, and Rocío Mejía in Leticia, and of Hernando and Priscilla Vidal in Bogotá, this study could not have been possible. We thank the U.S. National Marine Fisheries Service for allowing the participation of Barlow in the cruise. Participation of Vidal was possible thanks to a sabbatical granted by ITESM-Campus Guaymas thanks to the efforts of Luis Müggenburg and José Treviño. The help of Lloyd T. Findley in the design of the original overall project is greatly appreciated. The manuscript was improved by reviews of J. Laake, S. Leatherwood, and B. Würsig. This study was conducted under scientific research permit number 0517 issued by INDERENA. 


\section{Literature Cited}

Barlow, J. 1988. Harbor porpoise (Pbocoena phocoena) abundance estimation in California, Oregon and Washington: I. Ship surveys. Fishery Bulletin, U.S. 86:417432.

BarLow, J. 1995. The abundance of cetaceans in California waters. Part I: Ship surveys in summer and fall of 1991. Fishery Bulletin, U.S. 93:1-14.

Best, R. C., ANd V. M. F. Da Silva. 1989. Biology, status and conservation of Inia geoffrensis in the Amazon and Orinoco river basins. Pages 23-34 in W. F. Perrin, R. L. Brownell, Jr., Z. Kaiya, and L. Jiankang, eds. Biology and conservation of the river dolphins. IUCN/SSC Occasional Papers 3, Gland, Switzerland.

Borobia, M., S. Srciliano, L. Lodi and W. Hoek. 1991. Distribution of the South American dolphin Sotalia fuviatilis. Canadian Journal of Zoology 69:1025-1039.

Buckland, S. T., D. R. Anderson, K. P. Burnham and J. L. Laake. 1993. Distance sampling: Estimating abundance of biological populations. Chapman and Hall, London, England.

Hammond, P. S. 1986. Line transect sampling of dolphin populations. Pages 251279 in M. M. Bryden and R. Harrison, eds. Research on dolphins. Clarendon Press, Oxford, England.

Herman, L. M., L. von Fersen and M. Solangr. 1996. The bufeo (Inia geoffrensis) in the Río Lagarto Cocha of the Ecuadorian Amazon. Marine Mammal Science 12: $118-125$.

INDERENA. 1984. Parque Nacional Natural Amacayacu. Pages 215-221 in Colombia: Parques naturales. INDERENA, Bogotá, Colombia.

KasuYa, T., AND T. Kajihara. 1974. Ecology of dolphins in the Amazon and Orinoco systems. Pages 7-11 in Scientific expeditions of $\mathrm{La}$ Plata and Amazonian dolphins. University of Tokyo, Freshwater dolphin expedition, Tokyo. (In Japanese).

KIINOwsKA, M. 1991. Dolphins, porpoises and whales of the world. The IUCN Red Data Book. International Union for the Conservation of Nature and Natural Resources, Gland, Switzerland, and Cambridge, England.

LaAke, J. L., S. T. Buckland, D. R. Anderson and K. P. Bitrnham. 1993. DisTANCE user's guide. Colorado Cooperative Fish and Wildlife Research Unit, Colorado State University, Fort Collins, CO 80523, USA.

LAYNe, J. N. 1958. Observations on freshwater dolphins in the upper Amazon. Journal of Mammalogy 39:1-22.

LeATHER wOOD, S. 1996. Distributional ecology and conservation status of river dolphins (Inia geoffrensis and Sotalia futviatilis) in portions of the Peruvian Amazon. Ph.D. dissertation, Texas A\&M University. 233 pp.

Leatherwood, S., AND R. R. Reeves. 1994. River dolphins: A review of activities and plans of the Cetacean Specialist Group. Aquatic Mammals 20:137-154.

Magnusson, W. E., R. C. Best AND V. M. F. DA Sidva. 1980. Numbers and behaviour of Amazonian dolphins, Inia geoffrensis and Sotalia fluviatilis fuviatilis, in the Rio Solimoe, Brasil. Aquatic Mammals 8:27-32.

Meade, R. H., and I. Konhnken. 1991. Distribution of the river dolphin, tonina Inia geoffrensis, in the Orinoco River basin of Venezuela and Colombia. Interciencia 16:330-342.

Perrin, W. F., AND R. L. Brownell, JR. 1989. Report of the workshop. Pages 1-22 in W. F. Perrin, R. L. Brownell, Jr., Z. Kaiya, and L. Jiankang, eds. Biology and conservation of the river dolphins. IUCN/SSC Occasional Papers 3, Gland, Switzerland.

Perrin, W. F., R. L. Brownell, JR., Z. Kaiya and L. Jiankang. 1989. Biology and conservation of the river dolphins. IUCN/SSC Occasional Papers 3, Gland, Switzerland.

Pilleri, G., AND M. Grhr. 1977. Observations on the Bolivian (Inia boliviensis, d'Orbigny, 1834) and the Amazonian bufeo (Inia geoffrensis, de Blainville, 1817) 
with a description of a new subspecies of Cetacea. Investigations on Cetacea 8: $11-76$

ReEves, R. R., AND S. Leatherwood. 1994. Dolphins, porpoises, and whales: 19941998 action plan for the conservation of cetaceans. IUCN, Gland, Switzerland. $92 \mathrm{pp}$.

Reeves, R. R., and S. Leatherwood. 1995. Report of the first meeting of the Asian River Dolphin Committee, Ocean Park, Hong Kong, 5-7 December 1994. Ocean Park Conservation Foundation. 17 pp.

Reeves, R. R., A. A. Chaudhry and U. Khalid. 1991. Compering for water on the Indus plain: Is there a future for Pakistan's river dolphins? Environmental Conservation 18:341-350.

Reeves, R. R., S. Leatherwood and R. S. Lal Mohan. 1993. A future for Asian river dolphins: Report from a seminar on the conservation of river dolphins of the Indian Subcontinent, 18-19 August 1992, New Delhi, India. Whale and Dolphin Conservation Society, Bath, Avon, England. 39 pp.

SEber, G. A. F. 1982. The estimation of animal abundance. 2nd Ed. Charles Griffin and Company LTD, London, England.

Shane, S. H. 1990. Behavior and ecology of bottlenose dolphins at Sanibel Island, Florida. Pages 245-265 in S. Leatherwood and R. R. Reeves, eds. The bottlenose dolphin. Academic Press, San Diego, California, USA.

DA Silva, V. M. F. 1983. Ecologia alimentar dos golfinhos da Amazônia. M.Sc. thesis, Fundação Universidade do Amazônas/Instituto Nacional de Pesquisas da Amazônia, Manaus, Brazil. 112 pp.

DA Silva, V. M. F., AND R. C. BEST. 1994. Tucuxi Sotalia fluviatilis (Gervais, 1853). Pages 43-69 in S. H. Ridgway and R. Harrison, eds. Handbook of marine mammals. Vol. 5: The first book of dolphins. Academic Press, Cambridge, England.

Trujillo-G., F. 1994. The use of photoidentification to study the Amazon river dolphin, Inia geoffrensis, in the Colombian Amazon. Marine Mammal Science 10: $348-353$.

VIDAL, O. 1994. Status of dolphin populations in the upper Amazon River. Final report presented to the United Nations Environment Programme, Nairobi, Kenya, March, $57 \mathrm{pp}+$ annexes.

Received: 25 January 1996 Accepted: 8 March 1996

Note added in proof: In the 1996 IUCN Red List of Threatened Animals (IUCN 1996, IUCN Gland, Switzerland), Inia was classified as Vulnerable and Sotalia as Data Deficient. 